\title{
Effect of Composted Organic and Mineral Fertilizers Mixture on Some Important Characters of Potato Plants Grown in Desert Land
}

\author{
Hala Ahmed Abd El-Aal ${ }^{1}$
}

\begin{abstract}
Two field experiments were conducted at the Research Farm of the Environmental Studies and Research Institute, Menoufiya University, Sadat City, Egypt; during the two winter seasons of $2006 / 2007$ and $2007 / 2008$. The objective of this investigation was to study the effects of two methods of composite of organic and mineral fertilizers mixture through , two systems of fertilizing, i.e., external compost with mineral fertilizers, external compost with bio-fertilizer; internal compost with mineral fertilizers; and internal compost with bio-fertilizer as well as the control; on some characters of potato tubers of Diamont local cultivar.
\end{abstract}

The obtained results indicated generally that the most important findings were as follows:

- Plant height had the significantly highest value for the external compost with mineral fertilizer.

-The four treatments under study did not vary significantly regarding plant fresh weight being significantly higher than the control.

-Treatments of the external compost with mineral and biofertilizer and internal compost with bio-fertilizer gave highly significantly increment in tuber weight as compared to the control.

-The significantly highest total yield (ton/fed) was achieved by treatment of external compost with mineral and bio-fertilizer.

-Treatments of the external compost with bio-fertilizer and internal compost with bio-fertilizer gave significantly the highest tuber dry matter (\%).

- Starch and sugar content of tubers exhibited significantly different values due to the treatment applied and the season of growth.

In conclusion, despite the superiority of the four treatments to the control, the treatment of external compost with mineral fertilizers was the best in terms of improvement the vegetative and yield properties. This treatment was followed by the treatment of external compost with bio-fertilizer.

\section{INTRODUCTION}

Potato (Solanum Tuberosum,L.), is considered as one of the most important vegetable food crops for human all over the world. Potato tubers are an important source of digestible carbohydrates and dietary fibers as well as with some essential mineral elements. Meanwhile, potato is considered as a staple food that is consumed by the majority in a community in many countries. From the industrial point of view, potato is utilized to extract starch and flour and manufacture of glucose, alcohol and acetone (Sarhan et al., 2004 \& Alam et al., 2007).

Over the last few decades, consumers' demands for healthier food and government policies, focused on environmentally sustainable agricultural systems, have both promoted a rapid expansion of organic farming. Potato represents a major food crop in many countries where the demand for organic products is gradually increasing (Maggio et al., 2008).

It is well known that organic manure improved the structure of the soil and this consequently encourage the plant to have a good growth. The value of organic fertilizers as a source of nutrients for potato plants has been reviewed by many investigators such as Striban et al., (1984); Borin et al (1987) and Grewal (1990). on the composition between conventional integrated and organic cropping systems of some potato cultivars, Varis et al. (1996) found that $\mathrm{N}$ supply, total yield, storage losses and incidence of late blight were dependent systems. Yields were lower with organic production and potato "quality" factors varied in response to the various used treatments.

Järvan and Edesi (2009), studied the following cultivation methods; organic without manure, organic with cattle manure and conventional manure and mineral fertilizers, and pesticides. The results illustrated that in organic cultivation, the manure fertilization manure increased the potato yield with average of $36.5 \%$. Also, the dry matter content in tubers decreased; but, the nitrate content increased. Concerning the conventional farming methods, the yield was $127 \%$ higher than in the variant organic. The obtained results showed that the tubers' content of dry matter, starch and minerals were higher in organic cultivation than those in conventional cultivation. As for the content of reducing sugars, crude protein and nitrates, insignificant differences were detected between the two cultivation methods.

Impact of farmyard, manure and manure compost tea on potato yield and soil fertility were investigated by ElTantawy et al. (2009). The results indicated that addition of farmyard and manure into the soil increased

${ }^{1}$ Environmental Studies and Research Institute, Menoufiya University, Sadat Branch, Egypt

Received September 01, 2011, Accepted September25, 2011 
the total and available $\mathrm{N}$, phosphorus and potassium in the soil. On the other hand, compost fertilizers led to increased plant height, moisture content of leaves and stems, number of leaves, surface area of leaf and the chlorophyll content. The obtained results showed also that organic fertilizers elevated yield, moisture of tubers, crude protein content, starch content and specific gravity of potato tubers. As the concentration of compost increased as nitrogen, phosphorus and potassium contents of tubers, dramatically, increased.

The effects of the three mineral fertilizers i.e.; nitrogen, phosphorous and potassium, individually or in combination with either one or more of each with organic manure fertilizers on potato plants were studied by several researched such as Spoil and Fedotona (1987), Das and Banerjee (1996) and Singhand Kushwah (2006). The main objective of the present study was carried out in an attenpt to minimize the deteriorated effects of mineral fertilizers in the production of potato tubers by using organic sources. This study was conducted to investigate the effects of two ways of compost of organic and mineral fertilizers through two systems of fertilization on some growth, yield and its components characters as well as chemical composition of potato plants.

\section{MATERIALS AND METHODS}

Two field experiments were conducted, during the two winter seasons of 2006/2007 and 2007/2008 at the Research Farm of the Environmental Studies and Research Institute of Menoufiya University, Sadat City, Egypt.

In both experiments, the used experimental layout was a randomized complete blocks design (RCBD) with four replications. Each replicate consisted of five treatments; representing the combinations among the used fertilizers.

The area of each plot was $63 \mathrm{~m}^{2}(9 \mathrm{~m}$ length $\mathrm{x} 7 \mathrm{~m}$ width), including, 5 ridges, $1.4 \mathrm{~m}$ apart, $9 \mathrm{~m}$ long with plant spacing $25 \mathrm{~cm}$.

The study included two ways of composting organic and mineral fertilizers mix; namely, external (above the soil surface) and internal (under the soil surface), and two systems of fertilization. The first system included mineral fertilization $\left[20 \mathrm{~m}^{3}\right.$ cattle manure $+5 \mathrm{~m}^{3}$ chicken manure $+200 \mathrm{~kg}$ ammonium sulphate $(20.5 \%)$ $+150 \mathrm{~kg}$ calcium super phosphate $(15.5 \%)+25 \mathrm{~kg}$ magnesium sulphate $+125 \mathrm{~kg}$ agricultural sulphur]. The second one included bio-fertilization $\left[20 \mathrm{~m}^{3}\right.$ cattle manure $+5 \mathrm{~m}^{3}$ chicken manure $+70 \%$ of the mineral fertilizers that mentioned above $(140 \mathrm{~kg}$ ammonium sulphate $(20.5 \%)+105 \mathrm{~kg}$ calcium super phosphate $(15.5 \%)+17.5 \mathrm{~kg}$ magnesium sulphate $+87.5 \mathrm{~kg}$ agricultural sulphur) +400 gm of the bio-fertilizer Halix ${ }_{2}$ $+100 \mathrm{~g}$ humic acid per feddan], which was prepared before planting by about 30 days before planting above the soil surface for the external compost way and under the soil in cultivation rows for the internal compost. In the control treatment the usually recommended quantities of organic and mineral fertilizers during preparation and growth; $20 \mathrm{~m}^{3}$ cattle manure/fed. +150 $\mathrm{kg} \mathrm{N} /$ fad. $+75 \mathrm{~K}_{2} \mathrm{O}+75 \mathrm{~kg} \mathrm{P}_{2} \mathrm{O}_{5}$ /fed. at one week before planting. The external compost was also added at one week before cultivation. All treatments were conducted in parallel at the same time.

After one month of cultivation, the following components were added: $130 \mathrm{~kg}$ ammonium nitrate + $100 \mathrm{~kg}$ potassium sulphate + one $\mathrm{kg}$ humic acid +20 liter phosphoric acid / fed. with irrigation. The irrigated water was added three times per week in the system of mineral fertilization, and $70 \%$ of irrigated water amount was applied for bio-fertilization with $\mathrm{Halix}_{2}$ twice (the first after month from cultivation and the second a month after that) (400 g/fed with irrigation). The potato plants were sprayed after 25, 40 and 55 days of cultivation with foliar fertilizers containing $\mathrm{Fe}, \mathrm{Zn}, \mathrm{Mn}$, amino acid, citric acid, potassium and micro sulphur. This protocol was applied for both the mineral and the bio- fertilization. The spray of control was undertaken with micronutrients only. Prior to the initiation of each experiment, soil samples were collected and analyzed according to the published method that described by Page et al. (1982) The results of the soil analysis are given in Table (1), as average for the two seasons of $2006 / 2007$ and 2007/2008. The analysis of the chemical properties of the used chicken and cattle manures; which were analyzed according to Page et al. (1982); are presented in Table 2. The soil analysis was carried out according to the methods described by Page et al (1982) , and the chicken and cattle manures (Table 2) were prepared according to the methods described also by Page et al (1982).

Concerning the planting potato, the potato tubers of Diamont local cultivar were planted on one side of the ridge at $25 \mathrm{~cm}$ apart on 15 October and 18 October of the two seasons of 2006/2007 and 2007/2008, respectively. During the two growing seasons, all other agricultural practices such as irrigation, diseases, pests and weed control programs were performed whenever they appeared to be necessary.

Harvesting was conducted in February 2007 and 2008. The following parameters were recorded, immediately after harvesting; plant height $(\mathrm{cm})$, plant fresh weight $(\mathrm{kg})$ leaves dry matter content $(\%)$ number of branches plant ${ }^{-1}$,tuber weight of $(\mathrm{kg})$, tubers yield 
Table 1. Average physical and chemical properties of the soil analysis in the experimental sites, during the two winter seasons of $2006 / 2007$ and $2007 / 2008$

\begin{tabular}{|c|c|c|c|c|c|c|c|c|c|c|c|}
\hline \multicolumn{12}{|c|}{ A. Physical properties } \\
\hline \multirow{2}{*}{$\mathrm{CaCO}_{3}$} & \multirow{2}{*}{\multicolumn{3}{|c|}{ Organic matter, $\%$}} & \multicolumn{5}{|c|}{ Particle size distr., \% } & \multirow{2}{*}{\multicolumn{3}{|c|}{$\begin{array}{l}\text { Texture } \\
\text { class }\end{array}$}} \\
\hline & & & & & Sand & & Silt & Clay & & & \\
\hline 4.90 & \multicolumn{3}{|c|}{0.36} & & 81.25 & & 7.5 & 11.25 & \multicolumn{3}{|c|}{ Sandy } \\
\hline \multicolumn{12}{|c|}{ B. Chemical Properties } \\
\hline \multirow{2}{*}{$\mathbf{p} \mathbf{H}^{*}$} & \multirow{2}{*}{$\begin{array}{c}\mathbf{E} \mathbf{C}^{* *} \\
\text { mohs/cm }\end{array}$} & \multicolumn{4}{|c|}{ Soluble cations $(\mathrm{meq} / \mathrm{L})$} & \multicolumn{3}{|c|}{$\begin{array}{r}\text { Macronutrients(ppm) } \\
(\mathrm{meq} / \mathrm{L})\end{array}$} & \multicolumn{3}{|c|}{ Soluble anions } \\
\hline & & $\begin{array}{c}\mathrm{Ca} \\
++\end{array}$ & $\mathrm{Mg}^{++}$ & $\mathrm{K}^{+}$ & $\mathrm{Na}^{+}$ & total $\mathrm{N}$ & available $P$ & available $\mathrm{K}$ & $\mathrm{HCO}_{3}^{-}$ & $\mathrm{Cl}^{-}$ & $\mathrm{SO}_{4}^{--}$ \\
\hline 7.63 & 1.78 & 0.36 & 0.33 & 0.14 & 0.56 & 4.24 & 53 & 110 & 0.41 & 0.36 & 0.61 \\
\hline
\end{tabular}

*In the 1:2.5 soil: water suspension.

**In the soil paste extract

Table 2. Chemical properties of cattle and chicken manures, during the two seasons of 2006/2007 and 2007/2008

\begin{tabular}{|c|c|c|}
\hline Content & Cattle & Chicken \\
\hline $\mathrm{C} / \mathrm{N}$ ratio & 32.0 & $15.45: 1$ \\
\hline O.M\% & 44.0 & 59.1 \\
\hline $\mathrm{pH}$ & 9.15 & 8.35 \\
\hline $\mathrm{Ec} \mathrm{ds} / \mathrm{m}$ & 5.63 & 4.43 \\
\hline $\mathrm{N} \%$ & 0.84 & 2.07 \\
\hline $\mathrm{P} \%$ & 2.02 & 3.15 \\
\hline $\mathrm{K} \%$ & 1.55 & 3.0 \\
\hline $\mathrm{Ca} \%$ & 8.53 & 4.05 \\
\hline $\mathrm{Mg} \%$ & 10.51 & 1.35 \\
\hline Fe ppm & 3411 & 702 \\
\hline Mn ppm & 172 & 136 \\
\hline $\mathrm{Zn} \mathrm{ppm}$ & 53 & 193 \\
\hline $\mathrm{Cu}$ ppm & 21 & 25 \\
\hline
\end{tabular}

plant $^{-1}(\mathrm{~kg})$, total tubers yield tons fad $^{-1}$., number of tubers plant $^{-1}$ and tuber dry matter $(\%)$. Random samples of leaves and tubers from each treatment were collected, washed, dried in an oven at $65^{\circ} \mathrm{C}$ for $48 \mathrm{hr}$ and ground to pass 40 mesh screen and wet-digested with $\mathrm{H}_{2} \mathrm{SO}_{4}-\mathrm{H}_{2} \mathrm{O}_{2}$. The following determinations were carried out in the digested solution; N, P, and K; according to Jackson (1973); starch was determined according to A.O.A.C. (1990). To determine the percentage of total sugars, the method of Dubios et. al. (1972) were used, and total soluble solids, was measured using digital pocket refractometer.

All obtained data were collected and statistically analyzed. Duncan's multiple range test was used to compare the differences among the means of the various studied characters as affected by the treatments as illustrated by Steel and Torrie (1984).

\section{RESULTS AND DISCUSSION}

Vegetative Growth Characteristics
The results given in Table 3 revealed that the external compost along with mineral fertilization reflected, significantly, the highest plant height $(60.37$ $\mathrm{cm}, 57.5 \mathrm{~cm})$ as compared to the control $(34.0 \mathrm{~cm}$ and $43.5 \mathrm{~cm})$ in the first and second seasons, respectively and all other treatments, with only one exception in the second season. Meanwhile, insignificant differences, regarding the mean values of plant height were noticed as a result of the other treatments, in the first season. In contrast, in the second season, variations in plant height were observed due to applying the different investigated treatments in the present study, as compared with the control. It was noticed that the highest plant height was achieved when the internal compost with bio-fertilizer was conducted; followed by its counterpart of the mineral fertilizer, then the external compost of the mineral fertilizer; while, the plant height of control treatment tailed behind.

Table 3 indicated that insignificant differences, among the mean values of number of branches plant ${ }^{-1}$, could be figured out as a result of the used treatments 
in the present study, in the first season. On the other hand, internal compost with mineral fertilizers along with external compost with mineral fertilizers gave significantly the highest number of branches/plant in the second season.

Plant fresh weight $(\mathrm{kg})$ in the first season did not vary significantly for external compost with biofertilizer and external compost with mineral fertilizers and internal compost with bio-fertilizer (Table 3). In contrast, the four treatments under study did not vary significantly only regarding plant fresh weight $(\mathrm{kg})$ being significantly higher than the control.

The results revealed also that applying the external compost with mineral fertilizers resulted in a significant increment in percentage of dry matter content in leaves (16.27-15.73\%), followed by the external compost with the bio-fertilizer (12.93-11.73\%), as compared to the control, in both growing seasons.

Such results regarding the vegetative characters of potato plants, generally agreed with the results of numerous researchers (Awad, 2005; El-Morsy et al., 2006; Kabeel and Hasanin, 2006; Alam et al., 2007; Mirdad, 2010). Such results could be explained on the basis of the well known advantages of the compost, that could be summarized as follows; 1-high content of fertilizer elements, being in available form in addition to the organic matter at maturity completion of plant; 2absence of foreign seeds, microorganisms and nematode; 3 - presence of the activated compounds such as natural hormones and antibiotics required for plant growth, and 4- high ability of compost to keep water. In this respect, the forgoing results suggested generally that increasing the morphological characters of potato after application of the different compost of organic may be due to increasing the soil organic matter contents, cation exchange capacity and mineral nutrients, which in turn encouraged the plant growth to go forward.

\section{Yield and Yield Components:}

The results presented in Table 4 indicated that the external and internal compost with mineral fertilizers did not vary significantly and being the highest in terms of number of tubers/plant in the first season (Table 4). On the other hand external compost with mineral and bio-fertilizers, and internal compost with mineral fertilizers gave insignificant (and the highest) number of tubers/plant in the second season.

It was observed that external compost (with mineral and bio-fertilizers) along with internal compost with bio-fertilizer achieved the highest average tuber weight, as compared to the internal compost with mineral fertilizer, in the first season. In the second season, compost treatments with both fertilizers types resulted in significant increases of average weight of tubers, as relative to that of the control treatment. However, such an effect was more pronounced for the external compost with bio-fertilizer as compared to the control.

The external compost with mineral and bio-fertilizer gave significantly the highest tubers yield/plant $(\mathrm{kg})$ as compared to the other treatments and the control in the first seasons. No significant differences could be found in yield/plant for the external compost with mineral and bio-fertilizer and internal compost with mineral fertilizers in the second season (Table 4).

The significantly highest total yield (ton/fed) was achieved by external compost with mineral and biofertilizers in the first season. On the other hand total yield (ton/fed) did not vary significantly for external compost with mineral and bio-fertilizers and internal compost with mineral fertilizers in the second season.

Table 4 shows that external compost with biofertilizer and internal compost with bio-fertilizer gave significantly the highest tubers dry matter (\%) in the first season. Notwithstanding, the significantly highest tuber dry matter (\%) was achieved by treatment of the external compost with bio-fertilizer (Table 4). Generally, the presented results in regarding the effects of compost with bio-fertilizers on the potato characteristics, agree with the findings of several investigators such as Sherif et al., (2000); Shafeek et al.(2001); Sarhan et al.(2004); El-Morsy et al.( 2006) and Mirdad (2010). Also, the obtained results illustrated generally that using compost of organic and mineral fertilizers, reflected effects on the values of some yield and the component characters, in the growing seasons. Since, such result could be related to the vital role of organic increasing the availability of nutrient supply, improve the efficiency of macro-elements requirement of crop, which in turn, should be reflected on production of high yield.

\section{Chemical Composition of Leaves:}

Results presented in Table 5 that did not reveal significant differences in total sugar content of potato leaves in both seasons. This trend was also true for reducing sugar content in the first season, while treatments of external composting with bio-fertilizer and internal composting with mineral fertilizers gave significantly lower reducing sugar content than the control. As for non-reducing sugar content in potato leaves, no significant differences could be traced in both seasons. However, non-reducing sugar content exhibited significantly lower value for the control than the four treatments under study. 

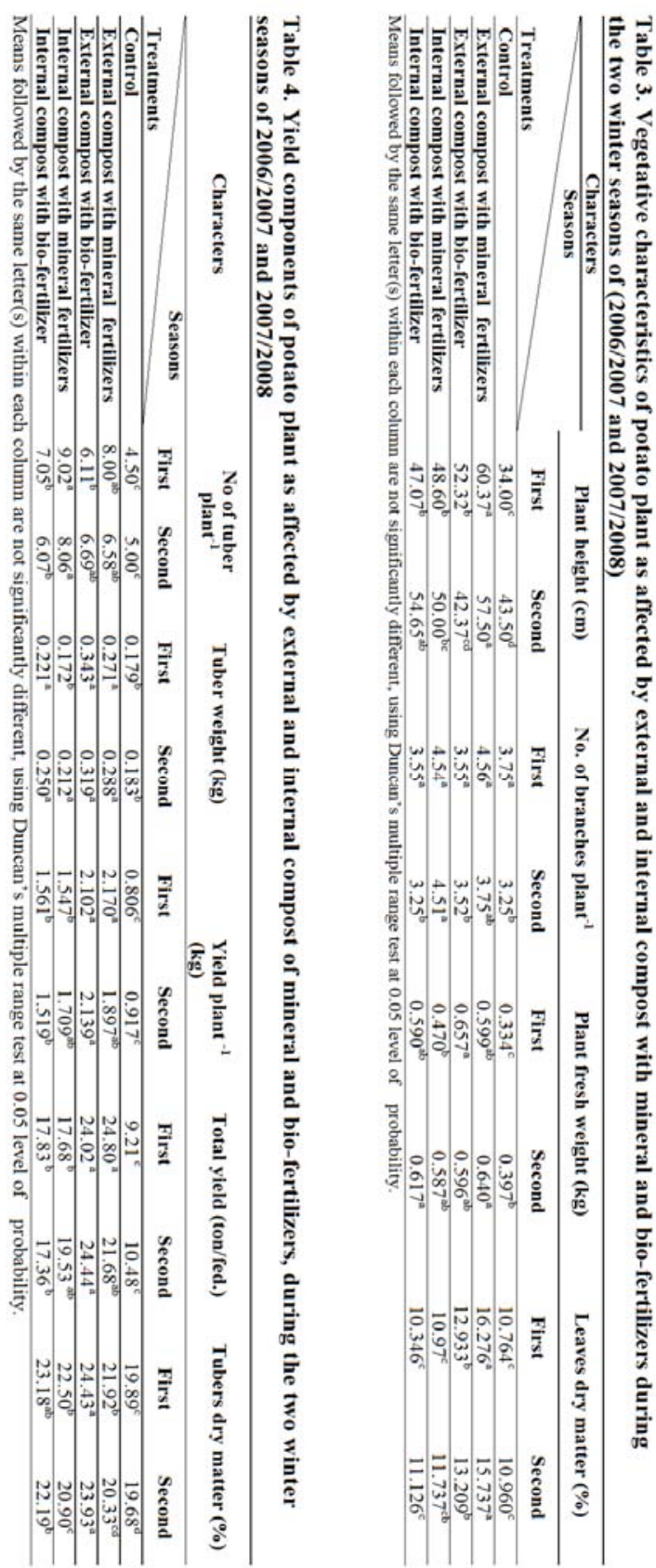


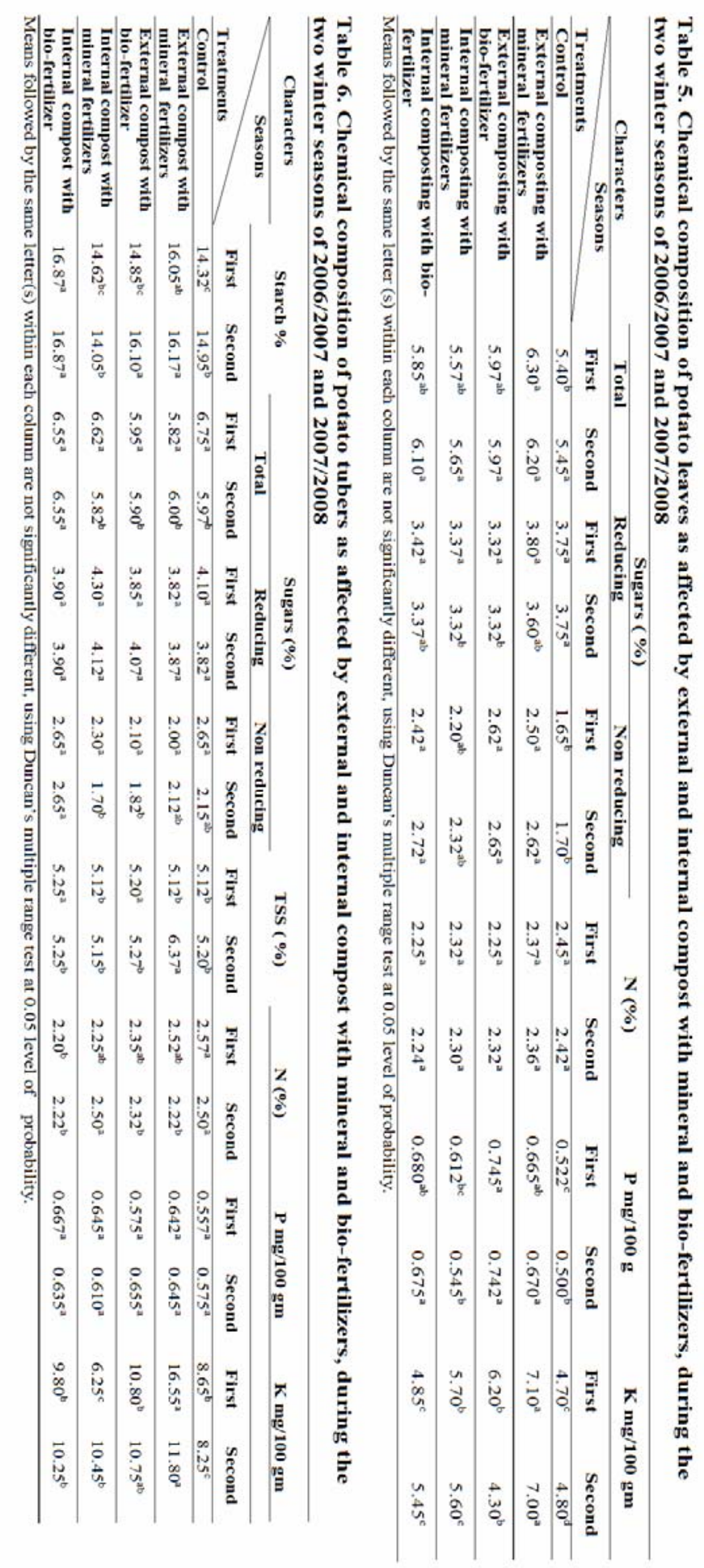


Nitrogen content in potato leaves did not explore any significant differences in both seasons for the four treatments applied in the present study as compared to the control (Table 5).

Table(5) shows that the control and treatment of internal composting with mineral fertilizers had significantly the least phosphorus content in potato leaves. This was true for both seasons.

Treatment of external composting with mineral fertilizers possessed significantly the highest potassium content of potato leaves. It was obvious that the control had significantly the least potassium content of potato leaves (Table 5).

Generally, such presented results appeared to be agreement with the findings of many other investigators (Adhikari and Sharma, 2004; Danilchenko et al., 2005 and Maggio et al., 2008).

\section{Chemical Composition of Potato Tubers:}

Treatments of the external composting with mineral fertilizers and internal composting with bio-fertilizer gave significantly the highest starch content in potato tubers in the first season. As for the second season, the control and treatment of internal composting with mineral fertilizers exhibited significantly lower starch content of tubers than the other treatments (Table 6).

In the first season, no significant differences in total sugar content of tubers could be figured out. On the other hand treatment of internal composting with biofertilizer gave significantly the highest total sugar content in tubers as compared to the control and the other treatments. Reducing sugar content in potato tubers did not vary significantly in both seasons for the control and the four treatments under study. The same trend could be noticed for non-reducing sugar content of potato tubers in the first season. Notwithstanding, in the second season, treatments of external composting with bio-fertilizer and internal composting with mineral fertilizers had significantly lower non-reducing sugars of tubers than the control and the other treatments (Table 6).

The total soluble solids (\%) exhibited significantly the highest values for treatments external composting with bio-fertilizer and internal composting with biofertilizer in the first season. On the other hand, no significant differences in T.S.S.\% of potato tubers could be found for the control and the treatments under study with treatment of external composting with mineral fertilizers being the exception since it had significantly the highest T.S.S.\% of tubers (Table 6).

Only treatment of internal composting with biofertilizer exhibited significantly lower N\% in tubers than the control in the first season. Meanwhile, treatment of internal composting with mineral fertilizers was the only treatment that did not vary significantly as compared to the control in terms of N\% of tuber in the second season, being the highest N\% (Table 6).

Table (6) shows that potassium content of potato tubers revealed significantly the highest value in the first season for treatment of external composting with mineral fertilizers. Meanwhile, treatments external composting with mineral fertilizers and external composting with bio-fertilizer had significantly the highest potassium content of potato tubers.

Generally, the obtained results herein concerning chemical composition of potato tubers, appeared to be in accordance with the results of Mirdad et al. (2010), who investigated effects of organic and mineral fertilizers on the chemical composition of potato tubers.

\section{Conclusion}

In a general conclusion, the four treatments of fertilization applied in the present study improved significantly the vegetative characteristics, yield and yield components, chemical composition of tubers and leaves as compared to the control. However, it was obvious that treatment of external composting with mineral fertilizers was superior to the other treatments along with the control. Meanwhile treatment of external composting with bio-fertilizer was the second treatment in this respect. In contrast, treatment of internal composting with mineral fertilizers and treatment of internal composting with bio-fertilizer came behind the former treatments.

\section{REFERENCES}

A.O.A.C. 1990. Association of Official Analytical Chemists, Official Methods of Analysis. $15^{\text {th }}$ Ed., Washington, D.C., USA.

Adhikari, R.C. and M.D. Sharma. 2004. Use of chemical fertilizers on Potatoes in sandy loam soil under humid sub-tropical condition of Chitwan- Nebal Agric. Res. J. 5:23-26.

Alam, M.N.; M.S. Jahan; M.K. Ali; M.A Ashraf. and M.K. Islam. 2007. Effect of vermicompost and chemical fertilizers on Growth, Yield and yield components of potato in Barind soils of Bangladesh. J. Appl. Sci. Res. 3 (2): $1879-1888$.

Awad, E.M. 2005. The influence of organic and mineral fertilization on growth yield and quality of Potato crop. J. Agric. Sci. Mansoura Univ. 30 (12): 7965-7975.

Borin,M.; C.Giupponi and F.Osele. 1987. The effect of organic and mineral fertilizer and soil type on potato tuber formation. Information Agrasio. 43: 91-92 (c.a. Field Crop Abst. 4, 8072, 1987). 
Danilchenko,V.; R. Dris and A. Niskanen, 2005. In fluence of organic and mineral fertilization on yield, composition and processing quality of potatoes. J. Food. Agric. \& Envir. 3 (1): 143-144.

Das,S.K. and N.C. Banerjee. 1996. Nutrient uptake of crops and fertility status of soil at different manorial treatments under potato based crop sequences. Potato Abst., 21 (4): 180.

Dubios, M; K. Gulles; J. Hamilton; P. Rebers and F. Smith .1972. Colourimetric method for determination of sugars and related substances. Analy. Chem. 28: 350-356.

El-Morsy,A.H.A.; E.N.El-Banna and M.M.B. Shokri .2006. Effect of some sources of organic manures and foliar spray with some micronutrients on productivity and quality of potato. J. Agric. Sci. Mansoura Univ. 31 (6): 3859-3868.

El-Tantawy, I.M.; M.A. El-Ghamry, and A.H. Habib .2009. Impact of farmyard manure and manure compost tea on potato yield and soil fertility. J. Agric. Sci. Mansoura Univ. 34 (1) : 669-678.

Grewal,J.S. 1990. Fertilizer use in potato crop in northwestern hills of India-Present status and future strategies. J. Indian Potato Assoc. 17 (1-2): 102-112.

Jackson, M.L. 1973. Soil chemical analysis. Prentice-Hall of India Private Limited, New Delhi, India.

Järvan, M. and L. Edesi .2009. The effect of cultivation methods on the yield and biological quality of potato. Agronomy Research 7(Special issue I), 289-299.

Kabeel, S.M.A. and N.M. Hasanin. 2006. Increasing potato productivity grown in sandy soil through organic and biofertilizers applications. J. Agric. Sci. Mansoura Univ. 31 (2): 951-962.

Maggio, A.; C. Petronia; S.A. Giovanni ; F. Amodio ; Gianarlo,B. and D.P. Stefania. 2008. Potato yield and metabolic profiling under conventional and organic farming. Europ. J. Agron.. 28: 343-350.
Mirdad, Z.M. 2010. The effect of organic and inorganic fertilizers application on vegetative growth, yield and its components and chemical composition of two potato (Solanum tuberosum, L.) cultivars. Alex. Sci. J. 31 (1):102- 120.

Page, A.L.; R.H. Miller and D.R. Keeney.1982. Methods of soil analysis. Part 2. ASA. SSSA. Madison, Wisconsin, USA.

Sarhan, S.H.; H.K. Zaki and; E.N. El- Banna .2004. Impact of organic and inorganic fertilization on yield, tuber contents and some heavy metals concentration in potato tubers. J. Agric. Sci. Mansoura Univ. 29 (5): 2753-2780.

Shafeek, M.R.; M. El-Desuki. and A.M. Shaheen. 2001. Growth and yield of some potato cultivars as affected by sources of fertilization. Egypt. J. Appl. Sci., 16 (4).

Sherif, F.K.; S.M. Arabi; M.N. Feleafel and I.M. Ghoneim. 2000. Effect of biofertilizer under varying sludge rates on growth, yield potentials and Elemental composition of potato (Solanum tuberosum, L.). Adv. Agric. Res. Vol. 5, No. 3.

Singh,S.P. and V.S.Kushwah. 2006. Effect of integrated use of organic and inorganic sources of nutrients on potato (Salanum tuberosum. L.) production. Indian Journal of Agronomy. 51 (3): 1-2.

Spoil, N.T. and L.S.Fedotova. 1987. Fertilizers and tuber quality. Kartofeli ovoshch'i 5:8 : 19. (c.a. Field Crop Abst., 41: 1349).

Steel, R.G.D. and J.H.Torrie .1984. Principles and procedures of statistics $2^{\text {nd }}$ Edition. McGraw Hill Book Co., Inc. Singapore, pp. 172-177.

Striban,M.; C.Deliv; C.Salontal,A.; Moraru and A.Suhov. 1984. Effect of cultivation technology on photosynthetic pigments and carbohydrates content of potato. (c.a. Field Crop Abst., 38, 6668).

Varis, E.; L.Pietila; K. Koikkalainen. 1996. Comparison of conventional, integrated and organic Potato production in field experiments in Finland. Acta Agric. Scand. Sect. B, Soil and Plant Sci., 46, 41-88. 


\section{إلمص لمص

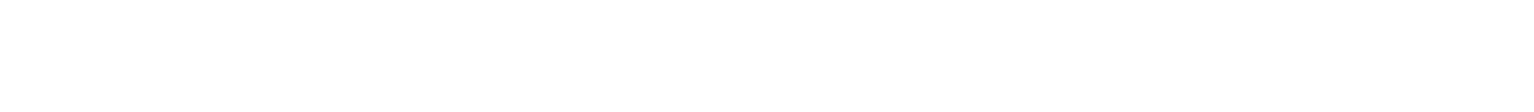

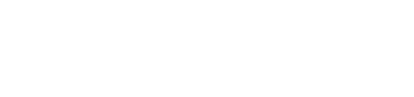 \\ هالة ألصدعبد العل ألصد}

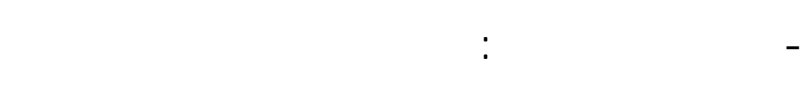

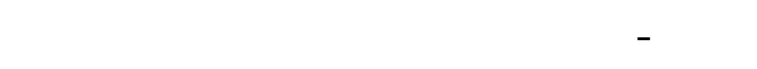

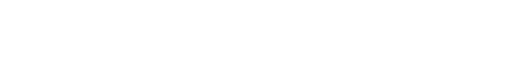

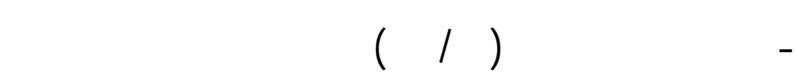

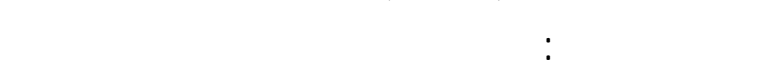

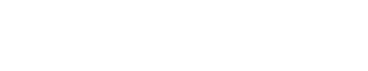

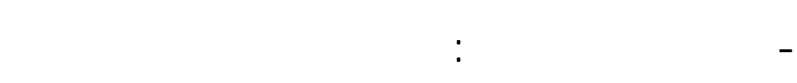

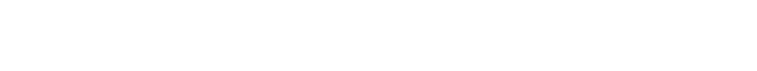

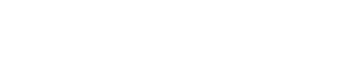

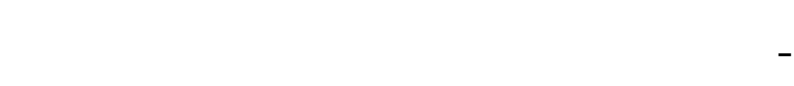
معنويا تبها للمعلماة للمستخدة وموسم الزراكة -

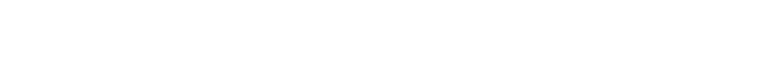

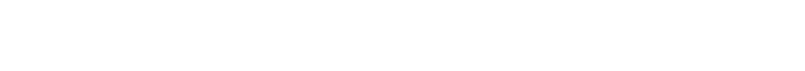

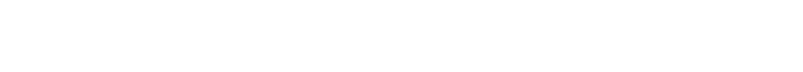

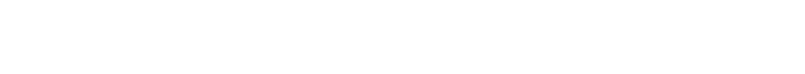
هي الأفل متبوكة [لعلاة الكمر الهارجي بالسماد المبوي.
أجريت هذه الدرلسة بالمركة البحثة [ـهعد الدرلست

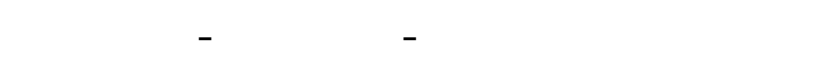

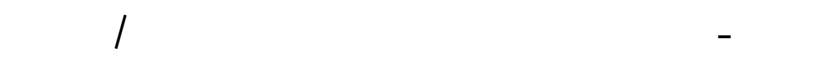

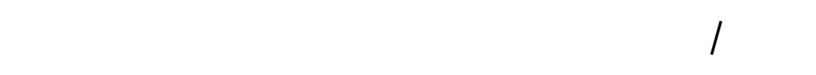

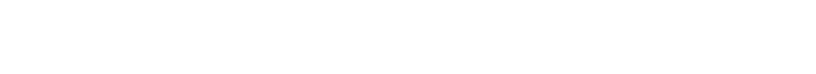

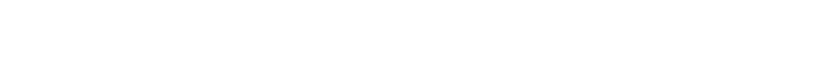

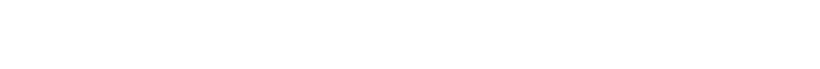

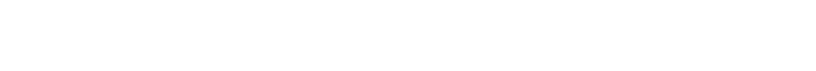

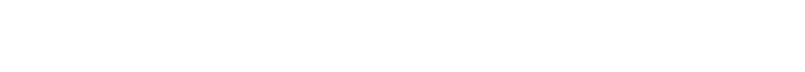

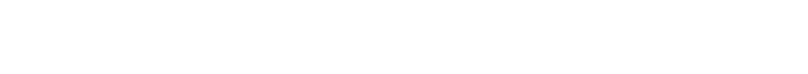

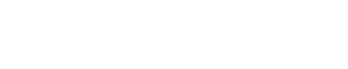
وفيما يلي أهم التنائج المنحطل عليها:

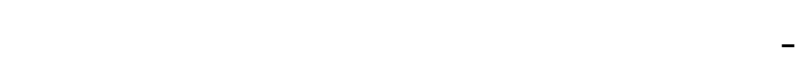

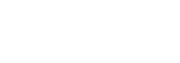

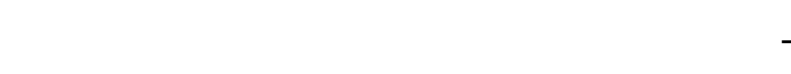

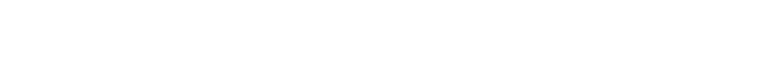
أعلي معنويا من متوبط معلمالة بالكترل - 